\title{
Herpes simplex virus type 1 related acute retinal necrosis following an encephalitis illness: a case report
}

\author{
Pingting Zhong ${ }^{1,2+}$, Siwen Zang ${ }^{1 \dagger}$, Honghua $\mathrm{Yu}^{1}$ and Xiaohong Yang ${ }^{1 *}$ (D)
}

\begin{abstract}
Background: Virus encephalitis is found to be a risk factor for acute retinal necrosis (ARN).

Case presentation: We herein presented a case of a 20-year-old teenage boy who suffered from encephalitis of unknown etiology with early negative pathologic results, and was primarily treated with systemic administration of high-dose steroids without antiviral therapy. He later had sudden vision loss in his right eye. Intravitreal and intravenous antiviral treatments were immediately started due to suspected ARN. Herpes simplex virus (HSV)-1 was identified later in the vitreous humor of the patient. After the surgery of retinal detachment (RD), obvious improvements in vision were observed. However, the patient had recurrent RD and vision declination 5 weeks later.

Conclusions: The case with suspected viral encephalitis should be treated with antiviral therapy regardless of early virologic results in order to avoid complications of a missed viral encephalitis diagnosis, especially if systemic steroid treatment is being considered.
\end{abstract}

Keywords: Acute retinal necrosis, Encephalitis, Herpes simplex virus, Steroids, Antiviral treatment

\section{Background}

Acute retinal necrosis (ARN) is a serious and potential blinding viral ocular infection, and it rapidly develops and progresses in immunocompetent people, causing uveitis with necrotizing retinitis [1]. Varicella-zoster virus (VZV) and herpes simplex virus (HSV) types 1 and 2 are the most common causative viruses of ARN [1]. It is assumed that reactivation amid immune dysfunction of the virus leads to ARN, along with central nervous system infection [2]. The association between viral encephalitis and ARN has been reported in one per 1.62.0 million people [3]. Therefore, additional attention with regard to ocular clinical manifestations is specially

\footnotetext{
* Correspondence: syyangxh@scut.edu.cn

'Pingting Zhong and Siwen Zang contributed equally to this work. 'Department of Ophthalmology, Guangdong Eye Institute, Guangdong Provincial People's Hospital, Guangdong Academy of Medical Sciences, Guangzhou 510080, China

Full list of author information is available at the end of the article
}

needed in patients with encephalitis after systemic treatment with steroids, as they could affect the body immunity and cause reactivation of the virus. Viral encephalitis should be aware of as it is a risk factor of ARN, and so antiviral treatment is recommended for suspected viral encephalitis.

\section{Case presentation}

A 20-year-old teenage boy with abrupt fever, confusion, and epileptic seizures was referred to the Department of Neurology of the Guangzhou General Military Hospital. The patient was otherwise a healthy boy until he had an unusual health status prior to 5 days. Cerebral spinal fluid (CSF) analysis was performed on admission, and the result showed negative Pandy test with a predominance of lymphocytes. Besides, CSF test for Mycobacterium tuberculosis, herpes simplex virus (HSV), cytomegalovirus (CMV), and rubella virus revealed negative results. Two days later, antibody analysis of autoimmune encephalitis

(c) The Author(s). 2021 Open Access This article is licensed under a Creative Commons Attribution 4.0 International License, which permits use, sharing, adaptation, distribution and reproduction in any medium or format, as long as you give appropriate credit to the original author(s) and the source, provide a link to the Creative Commons licence, and indicate if changes were made. The images or other third party material in this article are included in the article's Creative Commons licence, unless indicated otherwise in a credit line to the material. If material is not included in the article's Creative Commons licence and your intended use is not permitted by statutory regulation or exceeds the permitted use, you will need to obtain permission directly from the copyright holder. To view a copy of this licence, visit http://creativecommons.org/licenses/by/4.0/ The Creative Commons Public Domain Dedication waiver (http://creativecommons.org/publicdomain/zero/1.0/) applies to the data made available in this article, unless otherwise stated in a credit line to the data. 
was also shown to be normal. Brain magnetic resonance imaging (MRI) showed hypersignal intensity in bilateral frontal as well as temporal lobe.

Next, the patient was diagnosed with encephalitis due to unidentified etiology, and then systemic administration of steroids was given without antiviral treatment. He was prescribed with intravenous methylprednisolone, $1 \mathrm{~g} / \mathrm{d}$ for 3 consecutive days, followed by $0.5 \mathrm{~g} / \mathrm{d}$ for 3 days, and then was maintained on $80 \mathrm{mg} / \mathrm{d}$ for 2 weeks. Two weeks after admission, the boy showed no sign of improvement. A second brain MRI showed much worsened manifestation of hypersignal in both bilateral frontal and temporal lobe, and a second CSF analysis showed negative results of the pathogen as shown in the first CSF analysis. He was therefore presumed to have "autoimmune encephalitis" by primary neurologists and was prescribed with gamma globulin $25 \mathrm{~g} / \mathrm{d}$ for 5 days. Later, he had less fever and seizures, and improvements were observed in his oral expression. So, intravenous methylprednisolone administration was gradually reduced and replaced it by oral prednisone of $60 \mathrm{mg} / \mathrm{d}$ and then was discharged. One day after being discharged, he had sudden vision loss in his right eye, and then the boy was urgently referred to our hospital.

\section{Investigations}

After admitting in our hospital, the patient's physical and neurological exams were found to be unremarkable. His best corrected visual acuity (BCVA) showed light perception with correct light location in the temporal region of the right eye (OD), and 20/20 with that of the left eye (OS). Ophthalmological examination of his right eye revealed positive Tyndall $(+)$ and cell $(++)$ in the anterior chamber, with obvious opacity $(+++)$ in the vitreous chamber. The fundus of his right eye showed yellow-white lesions, with narrowing retinal vessels and white-sheath and peripheral hemorrhage. Also several tiny retinal holes that lead to retinal detachment (RD) were observed in the peripheral retina (Fig. 1a). No remarkable changes were observed in his left eye.

New brain MRI performed in our hospital suggested multiple abnormal signals in the brain parenchyma, which were in accordance with the manifestations of viral encephalitis (Fig. 2). So, viral-related retinal disorders were highly suspected in our case. Vitreous humor was obtained through vitreous chamber tapping to perform polymerase chain reaction (PCR) analysis. DNA of HSV-1 virus $\left(9.0 \times 10^{6} / \mathrm{ml}\right)$ was identified 5 days after intravitreal antiviral treatment, and the positive results of IgG and IgM antibodies in the blood serology also supported HSV-1 infection, thus confirming the diagnosis of ARN by HSV-1.

\section{Treatment}

Intravitreal administration of ganciclovir $(0.4 \mathrm{mg} / 0.1 \mathrm{ml})$ was immediately performed following vitreous chamber tapping at the time of admission to our hospital. Two days later, the boy was relieved from vitreous opacities $(+)$. Antiviral treatment was therefore considered to be effective, and broad-spectrum antiviral medicine (ganciclovir $250 \mathrm{mg}$ every 12 -h) was started intravenously, and then replaced with intravenous acyclovir (500 mg every 8-h) after confirmation of HSV pathogen. As the patient also suffered from $\mathrm{RD}$, his right eye was treated by pars plana vitrectomy (PPV), endolaser and silicone oil tamponade 3 days after admission. During the surgery, a second time intravitreal ganciclovir $(0.4 \mathrm{mg} / 0.1 \mathrm{mg})$ was given.

\section{Outcomes and follow-up}

The patient received intravenous antiviral treatment for 2 weeks and was discharged with oral antiviral medicine (famciclovir $375 \mathrm{mg}$ twice a day) as planned for 3 to 4 months. On the day of discharge, BCVA was 20/80 OD

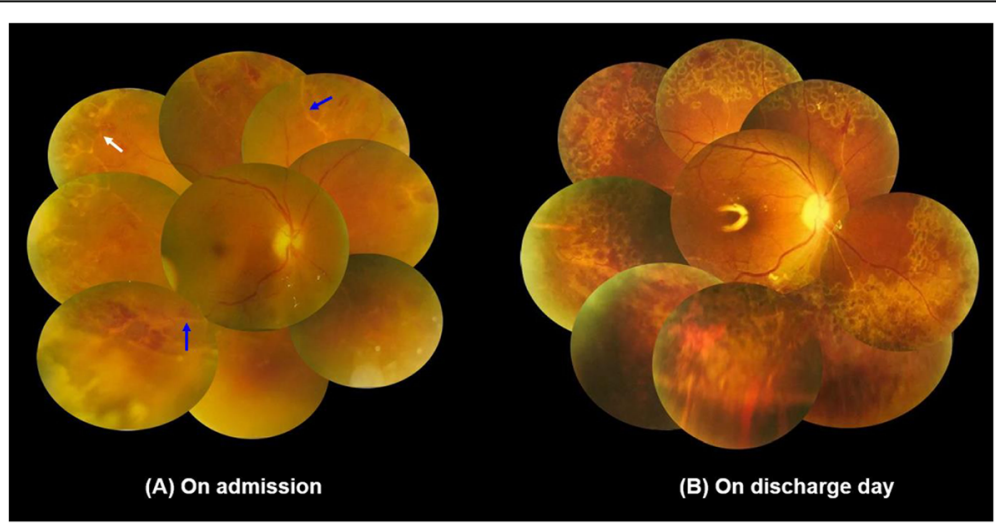

Fig. 1 Fundus photographs of the right eye. a On admission. The blue arrows represent severe occlusive vasculitis, with macula involved in the peripheral retina, and white arrow represents several tiny holes on superior-nasal degeneration area. b On discharge day. Retinal detachment was repaired with retinal vasculitis and edema showed great improvement 


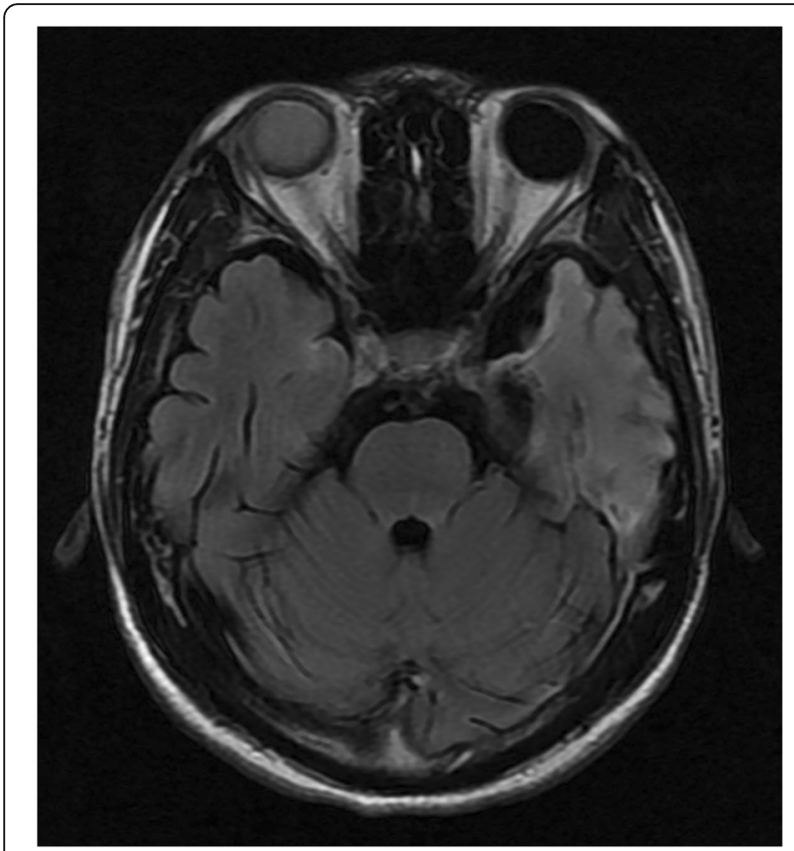

Fig. 2 Hypersignal intensity of left temporal lobe in MRI with T2 flair

and retinal edema in his right eye has been greatly relieved (Fig. 1b). At 5 weeks of follow-up, recurrent vision declination occurred with 20/500 OD due to recurrent RD (Fig. 3). Therefore, silicon oil displacement and endolaser were performed to repair the retina, as well as intravitreal ganciclovir $(0.4 \mathrm{mg} / 0.1 \mathrm{mg})$ was given for third time. The BCVA of his right eye was increased to 20/80 within 3 days after the surgery. Six months later, after removing the silicone oil, the BCVA was shown to be $20 / 200$ OD with complicated cataract.

\section{Discussion and conclusion}

Our patient due to encephalitis suffered from HSV related ARN after systemic administration of steroids. HSV-infected ARN could be a serious threat that leads to vision loss. Therefore, early awareness and timely antiviral treatment of suspected viral encephalitis are critical in such patients.

The possible reason for the cause of ARN in this patient might be due to viral encephalitis. HSV-1 virus encephalitis is usually characterized by altered mental health status, seizures, somnolence, increased cellularity with predominant lymphocytes in CSF, as well as hypersignal intensity in the MRI of temporal lobes [4], and all these clinical manifestations were observed in our patient. In our case, encephalitis was highly suspected to be caused by viral infection. However, lack of direct evidence of the virus in CSF impeded antiviral treatment. The patient later suffered from ARN due to HSV, suggesting that the virus might come from the brain. Due to the negative evidence in CSF, it could result in low positive predictive value [5] or procedural-related problems. To repeat CSF analysis is important in suspected viral encephalitis. ARN has been reported in cases with prior [6], simultaneous [7], or post [8] presence of herpetic simplex encephalitis or meningitis, and the interval between ARN and meningitis/encephalitis varied from 2 to 5 weeks [9]. A possible underlying mechanism has demonstrated bidirectional fast-axonal transport in neurons [10], and the viral genes play a critical role for antegrade and retrograde axonal transportation.

Immunocompromise after systemic administration of high-dose steroids could be another possible reason for the triggering of ARN in the current case. There are several possible explanations for steroids contributing to the occurrence of ARN. Firstly, high-dose steroids might affect body immunity, promote viral replication, and worsen necrotizing retinopathy [11]. The virus might reach the eye from the brain by a trans-axonal route. Secondly, the triggering event of systemic administration of high-dose steroids could reactivate HSV infection [12], and the latent HSV in several sites is connected to the eye, finally resulting in herpetic ocular disease that involves the cornea, iris, or even the retina [13]. When treating patients with encephalitis, for whom systemic administration of steroids is an inevitable regimen,

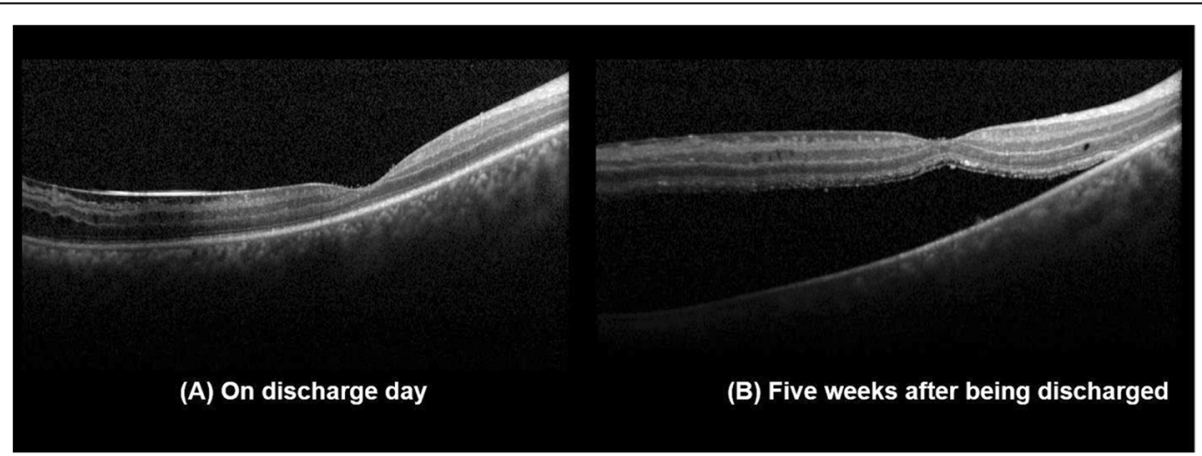

Fig. 3 OCT images of the right eye. a On discharge day and $\mathbf{b}$ at 5 weeks after discharge 
neurologists should be aware that it might lead to immunocompromise, posing a serious threat in triggering ARN. In addition, according to prior studies on treatment of HSV1-encephalitis by combining with acyclovir, a study showed that treatment without corticosteroid was associated with poorer outcomes [14], while another study found no positive effects by adding dexamethasone to acyclovir [15]. Therefore, the use of corticosteroid therapy for viral encephalitis depends on the discretion of clinicians. As patients with encephalitis always present with confusion, which prevents them from timely and precise expression of their ocular discomforts, and so attention should be paid with regard to ocular clinical manifestations.

Intravitreal and intravenous antiviral treatment was then immediately started in this patient, and this is because of high suspicion of ARN according to ocular manifestations. So, diagnostic testing of vitreous humor before antiviral treatment has been done, and later corresponding adjustments were made. Topical and systemic antiviral treatment is an urgent need, as it is beneficial for the visual acuity and thus could decrease the risk of infection to the other eye [16]. As documented previously, there were up to $70 \%$ of untreated patients with bilateral ARN [17]. In our case, ARN was presented in a single eye, but it is assumed that the contralateral eye might also be affected if timely and precise antiviral treatment is not given. With a better understanding of antiviral treatment, the rate of bilateralization according to the recently reported studies on ARN has been found to be significantly decreased into $10-20 \%$ [18].

The challenges concerning diagnosis as well as prognosis were posed in this case. The CSF initially revealed negative results for viral encephalitis, and the diagnosis of ARN was later confirmed by PCR analysis with HSV1 in the vitreous humor, and this is widely available to clinicians with good sensitivity and specificity [19]. According to a recent study, the correlation of quantitative DNA PCR and clinical prognosis in ARN has revealed that a number of copies superior to $5.0 \times 10^{6} / \mathrm{ml}$ showed association with a higher probability of $\mathrm{RD}$ [20]. In our case, the quantitative DNA of HSV-1 was $9.0 \times 10^{6} / \mathrm{ml}$, suggesting a poor prognosis of vision in accordance with recurrent $\mathrm{RD}$ and vision declination during the followup period.

In the suspected case of viral encephalitis, antiviral therapy should be performed regardless of early PCR results to avoid complications of missed viral encephalitis, especially if systemic glucocorticoid therapy is being considered. Besides, special awareness and careful evaluation on neuro-ophthalmological assessment should be paid in any patients with a central nervous system disease. The clinical decision-making should be tailored to suit patients with ARN related to encephalitis, considering the extent and severity of the diseases and symptoms, as well as disease progression. Furthermore, consultation with a multidisciplinary team related to ophthalmology is highly recommended.

\section{Abbreviations}

ARN: Acute retinal necrosis; HSV: Herpes simplex virus; BCVA: Best corrected visual acuity; CSF: Cerebral spinal fluid; RD: Retinal detachment;

PCR: Polymerase chain reaction

\section{Acknowledgments}

We gratefully thank the patient and his parents for their kind participation in the study.

\section{Authors' contributions}

Z. PT and Z. SW wrote the manuscript, analyzed the data, and reviewed the literature. Y. HH performed the surgery. Z. PT and Z. SW collected ophthalmologic data and assisted in drafting the manuscript. $Y . \mathrm{HH}$ and $Y$. $\mathrm{XH}$ revised the manuscript and discussions. All authors read and approved the final manuscript.

\section{Funding}

This work was supported by Science and Technology Program of Guangzhou, China (202002020049) (Y. XH); Project of Investigation on Health Status of Employees in Financial Industry in Guangzhou (Z012014075) (Y. $\mathrm{XH}$

\section{Availability of data and materials}

All data generated or analyzed during this study are included in this article and are available from the corresponding author upon reasonable request.

Ethics approval and consent to participate

This study is a case report, the study design was approved by the ethics review board of the Guangdong Provincial People's Hospital, Guangdong Academy of Medical Sciences. Written informed consent was obtained from the participant.

\section{Consent for publication}

Written informed consent was obtained from the patient for publication of this case and any accompanying images. This report does not contain any personal information that could lead to the identification of the patient.

\section{Competing interests}

The authors declare that they have no competing interests.

\section{Author details}

${ }^{1}$ Department of Ophthalmology, Guangdong Eye Institute, Guangdong Provincial People's Hospital, Guangdong Academy of Medical Sciences, Guangzhou 510080, China. 'Shantou University Medical College, Shantou, China.

Received: 12 September 2020 Accepted: 27 January 2021

Published online: 02 February 2021

References

1. Schoenberger SD, Kim SJ, Thorne JE, Mruthyunjaya P, Yeh S, Bakri SJ, et al. Diagnosis and treatment of acute retinal necrosis: a report by the American Academy of ophthalmology. Ophthalmology. 2017;124(3):382-92. https:// doi.org/10.1016/j.ophtha.2016.11.007.

2. Rochat C, Polla BS, Herbort CP. Immunological profiles in patients with acute retinal necrosis. Graefes Arch Clin Exp Ophthalmol. 1996;234(9):54752. https://doi.org/10.1007/bf00448798.

3. Liang ZG, Liu ZL, Sun XW, Tao ML. Yu GP. Viral encephalitis complicated by acute retinal necrosis syndrome: a case report. Exp Ther Med. 2015;10(2): 465-7. https://doi.org/10.3892/etm.2015.2557.

4. Moon SM, Kim T, Lee EM, Kang JK, Lee SA, Choi SH. Comparison of clinical manifestations, outcomes and cerebrospinal fluid findings between herpes simplex type 1 and type 2 central nervous system infections in adults. J Med Virol. 2014;86(10):1766-71. https://doi.org/10.1002/jmv.23999. 
5. Broadhurst MJ, Dujari S, Budvytiene I, Pinsky BA, Gold CA, Banaei N. Utilization, yield, and accuracy of the FilmArray meningitis/encephalitis panel with diagnostic stewardship and testing algorithm. J Clin Microbiol. 2020;58(9):e00311. https://doi.org/10.1128/jcm.00311-20.

6. Vandercam T, Hintzen RQ, de Boer JH, Van der Lelij A. Herpetic encephalitis is a risk factor for acute retinal necrosis. Neurology. 2008;71(16):1268-74. https://doi.org/10.1212/01.wnl.0000327615.99124.99.

7. Ogura H, Fukae J, Kimura S, Aoki M, Nabeshima K, Nabeshima Y. Acyclovir resistant acute herpes simplex encephalitis associated with acute retinal necrosis: a case report and review of the literature. Rinsho Shinkeigaku. 2017:57(5):230-3. https://doi.org/10.5692/clinicalneurol.cn-000959.

8. Todokoro D, Kamei S, Goto H, Ikeda Y, Koyama H, Akiyama H. Acute retinal necrosis following herpes simplex encephalitis: a nationwide survey in Japan. Jpn J Ophthalmol. 2019;63(4):304-9. https://doi.org/10.1007/s10384019-00668-5.

9. Zhou C, Zhu L, Fang S. Fulminant bilateral acute retinal necrosis syndrome associated with viral encephalitis: a case report. Exp Ther Med. 2016;12(4): 2227-9. https://doi.org/10.3892/etm.2016.3594.

10. Smith GA, Gross SP, Enquist LW. Herpesviruses use bidirectional fast-axonal transport to spread in sensory neurons. Proc Natl Acad Sci U S A. 2001;98(6): 3466-70. https://doi.org/10.1073/pnas.061029798.

11. Kim SJ, Kang SW, Joo EY. An unusual case of herpes simplex viral encephalitis following acute retinal necrosis after administration of a systemic steroid. J Epilepsy Res. 2012;2(1):21-4. https://doi.org/10.14581/jer. 12006.

12. Tran TH, Stanescu D, Caspers-Velu L, Rozenberg F, Liesnard C, Gaudric A, et al. Clinical characteristics of acute HSV-2 retinal necrosis. Am J Ophthalmol. 2004;137(5):872-9. https://doi.org/10.1016/j.ajo.2003.12.036.

13. Labetoulle M, Maillet S, Efstathiou S, Dezelee S, Frau E, Lafay F. HSV1 latency sites after inoculation in the lip: assessment of their localization and connections to the eye. Invest Ophthalmol Vis Sci. 2003;44(1):217-25. https://doi.org/10.1167/iovs.02-0464.

14. Kamei S, Sekizawa T, Shiota H, Mizutani T, Itoyama Y, Takasu T, et al. Evaluation of combination therapy using aciclovir and corticosteroid in adult patients with herpes simplex virus encephalitis. J Neurol Neurosurg Psychiatry. 2005;76(11):1544-9. https://doi.org/10.1136/jnnp.2004.049676.

15. Martinez-Torres F, Menon S, Pritsch M, Victor N, Jenetzky E, Jensen $K$, et al. Protocol for German trial of acyclovir and corticosteroids in herpes-simplexvirus-encephalitis (GACHE): a multicenter, multinational, randomized, double-blind, placebo-controlled German, Austrian and Dutch trial [ISRC TN45122933]. BMC Neurol. 2008;8:40. https://doi.org/10.1186/1471-2377-840.

16. Hafidi M, Janin-Manificat H, Denis P, Charleux B, Rabilloud M, Boibieux A, et al. Acute retinal necrosis: Virological features using quantitative polymerase chain reaction, therapeutic management, and clinical outcomes. Am J Ophthalmol. 2019;208:376-86. https://doi.org/10.1016/j.ajo.2019.08.007.

17. Palay DA, Sternberg P, Davis J, Lewis GN, Mieler WF, Jabs DA, et al. Decrease in the risk of bilateral acute retinal necrosis by acyclovir therapy. Am J Ophthalmol. 1991;112(3):250-5. https://doi.org/10.1016/s00029394(14)76725-X.

18. Lei B, Jiang R, Wang Z, Xu G, Xu X, Zhou M. Bilateral acute retinal necrosis: a case series. Retina. 2020;40(1):145-53. https://doi.org/10.1097/iae. 0000000000002341.

19. Cochrane TF, Silvestri G, McDowell C, Foot B, McAvoy CE. Acute retinal necrosis in the United Kingdom: results of a prospective surveillance study. Eye. 2012;26(3):370-7quiz 378. https://doi.org/10.1038/eye.2011.338.

20. Fang CM, Khan MA, Mehta S, Garg SJ, Dunn JP. Correlation of clinical outcomes with quantitative polymerase chain reaction DNA copy number in patients with acute retinal necrosis. Ocul Immunol Inflamm. 2017;25(2): 246-52. https://doi.org/10.3109/09273948.2015.1115081.

\section{Publisher's Note}

Springer Nature remains neutral with regard to jurisdictional claims in published maps and institutional affiliations.

Ready to submit your research? Choose BMC and benefit from:

- fast, convenient online submission

- thorough peer review by experienced researchers in your field

- rapid publication on acceptance

- support for research data, including large and complex data types

- gold Open Access which fosters wider collaboration and increased citations

- maximum visibility for your research: over $100 \mathrm{M}$ website views per year

At BMC, research is always in progress.

Learn more biomedcentral.com/submissions 